\title{
In Vivo Suppression of Bisphenol A on Estradiol 2- and 4-Hydroxylase Activities in Hepatic Microsomal Fractions of Male and Female Sprague-Dawley Rats
}

\author{
Boya Nugraha ${ }^{1,2}$, Aerin Yoon ${ }^{1}$, Lakshmi Devi Kandagaddala, ${ }^{1,2}$, Hyo Joo С ${ }^{1}$, \\ Bong Chul $\mathrm{CHUNG}^{1}$, and Oh-Seung KwON ${ }^{1,2, *}$ \\ ${ }^{1}$ Toxicology Lab., Bioanalysis and Biotransformation Research Center, Korea Institute of Science and Technology, \\ ${ }^{2}$ Biomolecular Sciences, University of Science and Technology, Seoul 136-791, Republic of Korea
}

(Received March 11, 2009; Revised April 6, 2009; Accepted April 21, 2009)

\begin{abstract}
This work was conducted to investigate the effect of bisphenol A (BPA) on estradiol (E2) 2-and 4-hydroxylase activities in the liver, kidney and lung tissues of male and female rats. After intraperitoneal administration of BPA to male and female rats for 4 days at 0,10 , and $50 \mathrm{mg} / \mathrm{kg}$, the conversion of the substrate for hepatic and extra-hepatic enzyme activities was measured by GC/MSD. The result showed decreases of body and organ weights at $50 \mathrm{mg} / \mathrm{kg}$ BPA of male and female rats. Male hepatic E2 2-hydroxylase activity was inhibited by $68 \%$ at $10 \mathrm{mg} / \mathrm{kg}$ and by $82 \%$ at $50 \mathrm{mg} / \mathrm{kg}$ BPA. Female hepatic E2 2-hydroxylase activity was decreased by $46 \%$ at $10 \mathrm{mg} / \mathrm{kg}$ and by $56 \%$ at $50 \mathrm{mg} / \mathrm{kg}$ to the control. E2 4-hydroxylase was inhibited by 57 and $57 \%$ at $10 \mathrm{mg} / \mathrm{kg}$ and 54 and $78 \%$ at $50 \mathrm{mg} / \mathrm{kg}$ in liver of female and male, respectively. The urinary excretion rate of 2-hydroxyestradiol (2-OHE), androsterone and testosterone in urine of female rats with $50 \mathrm{mg} / \mathrm{kg}$ BPA were decreased significantly. The results showed that $50 \mathrm{mg} / \mathrm{kg}$ BPA was decreased E2 2-and 4-hydroxylase activities in liver, but not in other tissues. The urinary excretion rates of 2-OHE, androsterone and testosterone were also decreased. In liver, estrogenic enzyme activity were higher in male than female. These results suggest that BPA can disrupt estrogen metabolism by suppressing E2 2-and 4-hydroxylase activities in the liver of male and female rats.
\end{abstract}

Keywords: Bisphenol A, Estradiol 2-hydroxylase, Estradiol 4-hydroxylase, Estrogen metabolites, Rat

\section{INTRODUCTION}

Bisphenol A (4,4'-isopropylidenediphenol, BPA) is a xenoestrogen used in the manufacture of polycarbonate plastics and epoxy resins that are useful as materials of many products, such as reusable milk and food storage containers, baby formula bottles, water pipes, and dental sealants (Brotons et al., 1995; Olea et al., 1996; Feldman, 1997; Noda et al., 1999). BPA is metabolized to 5-hydroxybisphenol and oxidized to bisphenol-o-quinone via 5-hydroxybisphenol and bisphenol semiquinone in male rats (Atkinson and Roy, 1995a, b). And DNA adducts with bisphenol-o-quinone were produced in vivo and in vitro. This adduct formation is markedly decreased by known in-

${ }^{*}$ Corresponding author

Tel: +82-2-958-5184 Fax: +82-2-958-5059

E-mail: oskwon@kist.re.kr hibitors of cytochrome P450 (CYP) (Atkinson and Roy, 1995b). And BPA inhibited various CYP activity in vitro such as CYP1A2, 2A2, 2B2, 2C11, and 3A2 (Hanioka et al., 2000), suggesting that BPA toxicity is closely related to the metabolism by CYP.

It has been summarized by Zhu and Conney that $17 \beta$ -estradiol (E2) was metabolized to 2-hydroxy estradiol (2-OHE) and 4-hydroxy estradiol (4-OHE) by E2 2-hydroxylase and E2 4-hydroxylase, respectively (Zhu and Conney, 1998). CYP1A1, 1A2, 1B1 and 3A4 had high activity for 2-OHE, and CYP1B1 predominantly catalyzed the formation of 4-OHE with other CYP isoforms such as CYP1A1, 1A2, 3A4, and 3A5 (Lee et al., 2003). Furthermore, these two metabolites were reported to be metabolized to E2-2,3-quinone and E2-3,4-quinone via its semiquinone intermediates, respectively (Zhu and Conney, 1998; Tsuchiya et al., 2005). These suggest that the metabolic pathways for estrogen may share common enzymes 
with BPA metabolism since the sequential hydroxylation and oxidation steps were involved in the production of either E2 or BPA metabolites. Therefore, the competition of BPA metabolism with E2 by various CYP isoforms is highly possible.

Hanioka et al. (1998) have reported that BPA inhibited CYP-dependent monooxygenase activities including E2 2-hydroxylase activity in the liver of male rats. No reports, however, on E2 4-hydroxylase activity in BPA-treated rats were found, and effects of BPA treatment on E2 2- and 4-hydroxylase activities in different gender and various kinds of organ tissues of rats still need to be studied.

This work is aimed at investigating whether BPA treatment has effects on E2 2- and 4-hydroxylase activities in liver, lung and kidney tissues of male and female rats, and whether it has effects on the change of urinary excretion rate of E2 and testosterone metabolites.

\section{MATERIALS AND METHODS}

\section{Chemicals}

Bisphenol A (purity $>99 \%$ ) was purchased from Aldrich (Milwaukee, WI, USA). All other chemicals were obtained from Sigma (St. Louis, MO, USA): benzphetamine- $\mathrm{HCl}, 17$ $\beta$-estradiol (purity $>98 \%$, E2), 2-hydroxyestradiol (purity $>$ $95 \%$, 2-OHE), 4-hydroxyestradiol (4-OHE), estrone (purit $y>99 \%$ ), methyltestosterone, androsterone (purity $>$ $97 \%$ ), testosterone (purity $>99 \%$ ), acetyl acetone, ammonium acetate, acetic acid, corn oil, nicotinamide adenine dinucleotide phosphate (NADP), paraformaldehyde, ascorbic acid, Tris- $\mathrm{HCl}, \mathrm{KCl}, \mathrm{MgCl}_{2}$, glycerol, sucrose, glucose-6-phosphate, glucose-6-phosphate dehydrogenase, HEPES, BCA-kit reagent, N-methyl-N-(trimethylsilyl)-trifluoroacetamide (MSTFA), ethylene-diaminetetraacetic acid (EDTA) and trimethylchlorosilane (TMCS). Methanol and ethyl acetate were purchased from J.T. Baker (Phillipsburg, NJ, USA). All the other chemicals were of analytical grade.

\section{Animals and BPA treatment}

Male and female Sprague-Dawley rats (6-week-old) were obtained from Samtako (Osan, Kyunggi, Korea). The rats were acclimated for at least 1 week under the control of constant temperature $\left(23 \pm 3^{\circ} \mathrm{C}\right)$ and humidity $(50 \pm$ 20\%). A 12-hr light/12-hr dark cycle was maintained beginning at 06:00 hr. Millipore-filtered tap water and feed (Samyang Co., Seoul, Korea) were provided ad libitum. The Internal Animal Care and Use Committee approved animal handling procedures for the experiment.

The rats were divided into 3 groups ( 5 rats/group/sex) of control, 10 and $50 \mathrm{mg} / \mathrm{kg}$ BPA treatment. BPA $(50 \mathrm{mg} / \mathrm{ml})$ was dissolved in corn oil, and $10 \mathrm{mg} / \mathrm{ml}$ was prepared by the dilution of $50 \mathrm{mg} / \mathrm{ml}$, and injected $(1 \mathrm{ml} / \mathrm{kg})$ intraperitoneally to rats at doses of 10 and $50 \mathrm{mg} / \mathrm{kg}$ per day for 4 consecutive days. Control groups were administered corn oil only.

\section{Collection of tissue and urine samples}

The urine samples were collected using metabolic cages at intervals of $0-24,24-48,48-72$ and $72-96 \mathrm{hr}$ in only female rats. The volume of urine collected was measured. One day after the last dose, the rats were sacrificed by decapitation. The trunk blood was collected. The liver, kidney, brain, lung, heart, spleen, thymus, and reproductive organs (testis and seminiferous tubule for male, and ovary and uterus for female rats) were dissected and the wet weight of the organs was recorded. The dissected tissues were frozen on dry ice and stored into a freezer $\left(-75^{\circ} \mathrm{C}\right)$ until analyzed.

\section{Preparation of microsomal fractions}

According to the method previously reported (Hanioka et al. 1998; Lee et al., 2008), the liver, kidney, and lung tissues frozen were weighed and thawed. Four volumes of $50 \mathrm{mM}$ Tris- $\mathrm{HCl}$ buffer ( $\mathrm{pH} 7.5$ ) containing $0.25 \mathrm{M}$ sucrose, $25 \mathrm{mM} \mathrm{KCl}$ and $5.0 \mathrm{mM} \mathrm{MgCl}_{2}$, were added to the weighed tissue to prepare homogenate in a glass-Teflon homogenizer and Overhead Stirrer (Wheaton, Millville, NJ, USA). The homogenate was centrifuged at $9,000 \mathrm{~g}$ for $20 \mathrm{~min}$, and the supernatant was collected and further centrifuged (Optima LE-80K; Beckman, Coulter, CA, USA) at 105,000 $\mathrm{g}$ for $60 \mathrm{~min}$. The resulting microsomal pellets were suspended with $50 \mathrm{mM}$ Tris-HCl buffer $(\mathrm{pH} 7.5)$ containing $0.15 \mathrm{M} \mathrm{KCl}$ and centrifuged at $105,000 \mathrm{~g}$ for $60 \mathrm{~min}$. The final pellets were suspended in $50 \mathrm{mM}$ Tris- $\mathrm{HCl}$ buffer containing $10 \%$ glycerol and stored at $-75^{\circ} \mathrm{C}$ until use. The protein content was determined using BCA kit and bovine serum albumin as the standard.

\section{Benzphetamine N-demethylase assay}

Benzphetamine $\mathrm{N}$-demethylase activity was determined by measuring the quantity of formaldehyde formed according to the method of Arinc et al. (2005) and Nash (1953). The enzyme reaction was consisted of $50 \mu \mathrm{l}$ microsomal fractions ( $0.2 \mathrm{mg}$ protein), $0.5 \mathrm{mM}$ benzphetamine- $\mathrm{HCl}$, $100 \mathrm{mM}$ HEPES buffer ( $\mathrm{pH}$ 7.7) and NADPH-generating system containing $0.5 \mathrm{mM} \mathrm{NADP}^{+}, 2.5 \mathrm{mM} \mathrm{MgCl}_{2}, 2.5 \mathrm{mM}$ glucose 6-phosphate, $0.5 \mathrm{U} / \mathrm{ml}$ glucose 6-phosphate dehydrogenase and 14.6 mM HEPES buffer ( $\mathrm{pH} 7.7)$ in a final volume of $0.3 \mathrm{ml}$. The tube was incubated for $45 \mathrm{~min}$ at $37^{\circ} \mathrm{C}$. The reaction was terminated by addition of $1.0 \mathrm{ml}$ of 
$0.75 \mathrm{~N}$ perchloric acid solution. To determine formaldehyde formation from benzphetamine, Nash reagent was added and heated at $60^{\circ} \mathrm{C}$ for $30 \mathrm{~min}$. After cooling, the absorbance was measured at $412 \mathrm{~nm}$ of a spectrophotometer (Cary 1E UV-Visible, Varian Inc., Palo Alto, CA, USA).

\section{Estradiol 2- and 4-hydroxylase assays}

E2 2- and 4-hydroxylase activities were established with modification of Wilson and Reed (2001) and Spink et al. (1990). Briefly, the activity was measured by addition of 40 $\mu \mathrm{M}$ E2 as the substrate $(4 \mu \mathrm{l}$ of $5 \mathrm{mM}$ E2 in methanol was added), $50 \mu \mathrm{l}$ microsomal fraction (>0.1 mg protein), $2 \mathrm{mM}$ ascorbic acid and NADPH-generating system that contained $1 \mathrm{U} / \mathrm{ml}$ glucose 6-phosphate dehydrogenase, $3 \mathrm{mM}$ $\mathrm{MgCl}_{2}, 1 \mathrm{mM}$ EDTA, $1 \mathrm{mM}$ NADP ${ }^{+}, 5 \mathrm{mM}$ glucose 6-phosphate, and $50 \mathrm{mM}$ phosphate buffer ( $\mathrm{pH} \mathrm{7.4)}$ in a final volume of $0.5 \mathrm{ml}$. The tubes were pre-incubated at $37^{\circ} \mathrm{C}$ for 5 $\mathrm{min}$, and the reaction was started by addition of $\mathrm{NADP}^{+}$ solution, and the tube was incubated for $10 \mathrm{~min}$ at $37^{\circ} \mathrm{C}$. Ethyl acetate of $5 \mathrm{ml}$ was added to the tube on ice. Methyltestosterone (200 ng; $20 \mu \mathrm{l}$ of $10 \mu \mathrm{g} / \mathrm{ml}$ in methanol) as an internal standard and $1 \mathrm{ml}$ of $1 \mathrm{M} \mathrm{K}_{2} \mathrm{CO}_{3}$ were added. After extraction on a shaker and centrifugation, the organic layer was collected and evaporated under nitrogen gas. The residue was derivatized with $50 \mu$ of MSTFA: TMCS $(100: 1, v / v)$ mixture at $60^{\circ} \mathrm{C}$ for $30 \mathrm{~min} .2 \mu \mathrm{l}$ of the solution was analyzed with a gas-chromatography/mass selective detector (GC/MSD).

\section{Determination of enzymatic products by a gas chro- matography/mass selective detector (GC/MSD)}

The determination of 2-OHE, 4-OHE, estrone and methyltestosterone was performed by using GC/MSD (HP 5890/HP 5972, Hewlett-Packard, Palo Alto, CA, USA) equipped with a capillary column of Ultra-2 $(17 \mathrm{~m}$, length $\times$ $0.2 \mathrm{~mm}$, inner diameter $\times 0.33 \mu \mathrm{m}$, film thickness; J\&W Scientific, Folsom, CA, USA). The samples were injected to the instrument by an auto liquid sampler (HP6890 Series), being supported with the GC/MSD ChemStation. The flow rate of helium as the carrier gas was $0.8 \mathrm{ml} / \mathrm{min}$ with $50 \mathrm{psi}$ of head pressure. The split ratio was $8: 1$ and the flow rate of the septum purge vent was $4 \mathrm{ml} / \mathrm{min}$. The injector of the gas chromatograph and transfer line of the ion source were set to $280^{\circ} \mathrm{C}$ and $300^{\circ} \mathrm{C}$, respectively. The initial oven temperature was set to $180^{\circ} \mathrm{C}$ at which the temperature was increased by a rate of $15^{\circ} \mathrm{C}$ per min to $260^{\circ} \mathrm{C}$ and stayed for $6 \mathrm{~min}$. The temperature was sequentially increased by $2^{\circ} \mathrm{C}$ per min from 260 to $275^{\circ} \mathrm{C}$ with holding time of $1 \mathrm{~min}$, and finally by $30^{\circ} \mathrm{C}$ per min from 275 to $300^{\circ} \mathrm{C}$ with holding time of $5 \mathrm{~min}$. Electron impact mode of the mass selective detector was used, and ionized energy of the mode was $70 \mathrm{eV}$. The electron multiplier voltage of the detector was $2,000 \mathrm{~V}$. The selected ion monitoring (SIM) mode was used. The selected ions for 2-OHE confirmation were $\mathrm{m} / \mathrm{z} 504,373$, and 267 . Ions of $\mathrm{m} / \mathrm{z} 504$, 373 , and 265 were selected for $4-\mathrm{OHE}$, and those selected for estrone were $\mathrm{m} / \mathrm{z} 342,257$, and 244 . The selected ions for methyltestosterone as an internal standard were $\mathrm{m} / \mathrm{z}$ 446 and 301. lons $\mathrm{m} / \mathrm{z} 272,347$ and 362 for androsterone, and $\mathrm{m} / \mathrm{z} 432,360$ and 417 for testosterone were detected. The ions used for quantitation were $\mathrm{m} / \mathrm{z} 504$ for 2-OHE and 4-OHE, $\mathrm{m} / \mathrm{z} 342$ for estrone, $\mathrm{m} / \mathrm{z} 446$ for methyltestosterone, $\mathrm{m} / \mathrm{z} 272$ for androsterone, and $\mathrm{m} / \mathrm{z} 432$ for testosterone.

\section{Determination of 17ß-estradiol metabolites by GC/MSD in urine of female rats}

E2 metabolites, androsterone and testosterone in urine samples were determined by GC/MSD with minor modification as previously reported in our lab (Lee et al., 2007). To $1 \mathrm{ml}$ of urine $100 \mu \mathrm{l}$ ascorbic acid $(1 \mathrm{mg} / \mathrm{ml})$ to protect oxidative reactions, methyltestosterone $(200 \mathrm{ng})$ as an internal standard, $1 \mathrm{ml}$ of $0.1 \mathrm{M}$ acetate buffer $(\mathrm{pH} \mathrm{5.2)}$ and $50 \mu \mathrm{l}$ of $\beta$-glucuronidase/arylsulfatase were added. The mixture was incubated in a heating block at $55^{\circ} \mathrm{C}$ for $3 \mathrm{hr}$ for hydrolysis. And then, $100 \mathrm{mg}$ of $\mathrm{K}_{2} \mathrm{CO}_{3}$ were added to adjust $\mathrm{pH}$ to 9.0 . The organic layer was extracted with $5 \mathrm{ml}$ ethyl acetate on a shaker for 20 min. After centrifugation, the organic layer was separated by using a freezer and evaporated under nitrogen gas. All other steps are the same as in described above.

\section{Statistical analysis}

All data are presented as mean \pm standard errors. The general linear model (GLM) procedure of SAS (SAS Institute Inc., Cary, NC, USA) was used. Duncan's multiple range test (MEANS) and probability difference (LSMEANS) were used for one way analysis of variance (ANOVA) when $F$-values showed significance. Student's $t$ test was used to compare gender difference in each group. Values were considered statistically significant at the level of $p<0.05$.

\section{RESULTS}

\section{Effects of BPA on body and wet organ weights}

Body weights were decreased in the group of both female and male rats exposed to $50 \mathrm{mg} / \mathrm{kg}$ BPA intraperitoneally for 4 consecutive days, beginning at day 3 in female and day 2 in male when these values are compared 

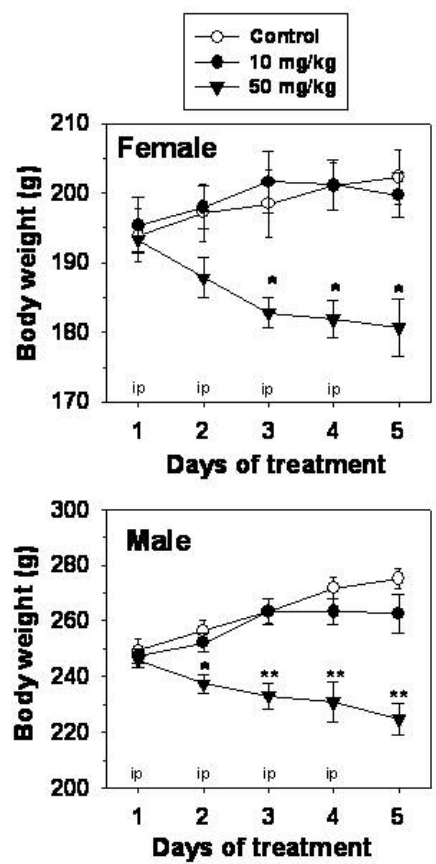

Fig. 1. Effects of BPA on body weights of female and male rats after intraperitoneal administration with 0,10 , and $50 \mathrm{mg} / \mathrm{kg} /$ day for 4 consecutive days. Body weights were significantly decreased at $50 \mathrm{mg} / \mathrm{kg} /$ day groups of female and male rats. Each value represents the mean \pm SEM of five rats/group/sex. The asterisks $\left({ }^{*}\right)$ indicate that the values are significantly different from the control $\left({ }^{*} p<0.05,{ }^{* *} p<0.005\right)$. to each day of the control group (Fig. 1). At the last day, body weights of $50 \mathrm{mg} / \mathrm{kg}$ BPA groups in female and male were decreased by 10.5 and $18.3 \%$, compared to each control group, respectively. And for $50 \mathrm{mg} / \mathrm{kg}$ dosed groups, significant decreases of the body weight in male rats were observed one day earlier than in female rats. These data indicate that BPA treatment has higher effects to male than female rats in the change of body weights. The body weights of rats given $10 \mathrm{mg} / \mathrm{kg}$ BPA were not changed in either male or female rats, compared to each control group.

Administration of $50 \mathrm{mg} / \mathrm{kg}$ BPA to rats resulted in decrease of organ weights in the liver, lung, kidney, heart, and thymus of female rats (Table I), and in the liver, lung, kidney, spleen, thymus and seminiferous tubule of male rats (Table II). No significant changes in reproductive organ weights of female rats were observed, even if the decreasing tendency was remarkable and ovary weights have boundary effects of statistical significance ( $p=0.059$ for ovary; Table I). The ratios of the wet organ to the body weight were decreased in the liver and thymus of female rats given $50 \mathrm{mg} / \mathrm{kg}$ BPA, compared to the control (Table I). The ratios of the wet organ to body weight were significantly changed in the liver, spleen, thymus, testis, and seminiferous tubule of male rats exposed to $50 \mathrm{mg} / \mathrm{kg}$ dose of BPA (Table II). The ratios of the wet spleen and reproductive organ to body weight were significantly decreased in male, but not female rats exposed to $50 \mathrm{mg} / \mathrm{kg}$

Table I. Wet organ weights and the ratios of organ to body weight of control and bisphenol A (BPA)-treated female rats

\begin{tabular}{lcccc}
\hline & Control & $10 \mathrm{mg} / \mathrm{kg} \mathrm{BPA}$ & $50 \mathrm{mg} / \mathrm{kg} \mathrm{BPA}$ & Probability $(\mathrm{P})$ \\
\hline Wet organ weights $(\mathrm{g})$ & & & & \\
$\quad$ Liver & $8.626 \pm 0.1625$ & $8.196 \pm 0.0991$ & $6.322 \pm 0.514^{* *}$ & 0.0005 \\
Lung & $1.1120 \pm 0.0296$ & $1.0940 \pm 0.0495$ & $0.918 \pm 0.026^{* *}$ & 0.0047 \\
Kidney (right) & $0.818 \pm 0.034$ & $0.806 \pm 0.034$ & $0.664 \pm 0.028^{* *}$ & 0.0097 \\
Heart & $0.876 \pm 0.0781$ & $0.826 \pm 0.029$ & $0.684 \pm 0.025^{*}$ & 0.0492 \\
Spleen & $0.576 \pm 0.040$ & $0.548 \pm 0.015$ & $0.440 \pm 0.068$ & 0.1336 \\
Thymus & $0.422 \pm 0.035$ & $0.548 \pm 0.0153$ & $0.188 \pm 0.017^{* *}$ & 0.0001 \\
Uterus & $0.560 \pm 0.129$ & $0.566 \pm 0.076$ & $0.326 \pm 0.025$ & 0.1287 \\
Ovary & $0.122 \pm 0.005$ & $0.106 \pm 0.005$ & $0.098 \pm 0.009$ & 0.0591 \\
Body weight & $202.30 \pm 3.90$ & $199.72 \pm 3.23$ & $180.70 \pm 4.19^{* *}$ & 0.0320 \\
Ratios to body weight & & & & \\
Liver & $0.0427 \pm 0.0011$ & $0.0411 \pm 0.0005$ & $0.0348 \pm 0.0021^{* *}$ & 0.0046 \\
Lung & $0.0055 \pm 0.0002$ & $0.0055 \pm 0.0002$ & $0.0051 \pm 0.0001$ & 0.1288 \\
Kidney (right) & $0.0040 \pm 0.0001$ & $0.0040 \pm 0.0001$ & $0.0037 \pm 0.0001$ & 0.0993 \\
Heart & $0.0043 \pm 0.0003$ & $0.0041 \pm 0.0002$ & $0.0038 \pm 0.0002$ & 0.3069 \\
Spleen & $0.0029 \pm 0.0002$ & $0.0027 \pm 0.0001$ & $0.0024 \pm 0.0003$ & 0.3947 \\
Thymus & $0.0021 \pm 0.0002$ & $0.0022 \pm 0.0001$ & $0.0010 \pm 0.0001^{* *}$ & 0.0002 \\
Uterus & $0.0028 \pm 0.0007$ & $0.0028 \pm 0.0004$ & $0.0018 \pm 0.0001$ & 0.2575 \\
Ovary & $0.0006 \pm 0.0000$ & $0.0005 \pm 0.0000$ & $0.0005 \pm 0.0000$ & 0.3431 \\
\hline
\end{tabular}

Each value represents the mean \pm SEM of five animals per group. ${ }^{* * \star}$ Significantly different from the control $\left({ }^{*} p<0.05,{ }^{* *} p<0.005\right)$. 
Table II. Wet organ weights and the ratios of organ to body weight of control and bisphenol A (BPA)-treated male rats

\begin{tabular}{lcccc}
\hline & Control & $10 \mathrm{mg} / \mathrm{kg} \mathrm{BPA}$ & $50 \mathrm{mg} / \mathrm{kg} \mathrm{BPA}$ & Probability $(\mathrm{Pr})$ \\
\hline Organ wet weights $(\mathrm{g})$ & & & & \\
$\quad$ Liver & $12.496 \pm 0.316$ & $10.950 \pm 0.822$ & $8.050 \pm 0.325^{\star *, \#}$ & 0.0003 \\
Lung & $1.340 \pm 0.073$ & $1.310 \pm 0.054$ & $1.050 \pm 0.041^{* *, \#}$ & 0.0070 \\
Kidney (right) & $1.126 \pm 0.039$ & $1.050 \pm 0.058$ & $0.856 \pm 0.022^{* *, \#}$ & 0.0021 \\
Heart & $1.036 \pm 0.048$ & $0.990 \pm 0.048$ & $0.856 \pm 0.059$ & 0.0745 \\
Spleen & $0.762 \pm 0.031$ & $0.722 \pm 0.040$ & $0.440 \pm 0.051^{* *, \#}$ & 0.0004 \\
Thymus & $0.636 \pm 0.039$ & $0.644 \pm 0.072$ & $0.300 \pm 0.033^{* *, \#}$ & 0.0006 \\
Testis & $3.082 \pm 0.119$ & $2.752 \pm 0.097$ & $2.708 \pm 0.096$ & 0.0522 \\
Seminiferous tubule & $0.534 \pm 0.045$ & $0.500 \pm 0.042$ & $0.346 \pm 0.026^{* *, \#}$ & 0.0104 \\
Body weight & $275.10 \pm 3.73$ & $262.60 \pm 6.86$ & $224.60 \pm 5.52^{* *}$ & $<0.0001$ \\
Ratios to body weight & & & \\
Liver & $0.0455 \pm 0.0014$ & $0.0415 \pm 0.0021$ & $0.0359 \pm 0.0015^{* *, \$}$ & 0.0052 \\
Lung & $0.0049 \pm 0.0002$ & $0.0050 \pm 0.0003$ & $0.0047 \pm 0.0002$ & 0.6215 \\
Kidney (right) & $0.0041 \pm 0.0002$ & $0.0041 \pm 0.0001$ & $0.0038 \pm 0.0001$ & 0.4021 \\
Heart & $0.0038 \pm 0.0002$ & $0.0038 \pm 0.0002$ & $0.0038 \pm 0.0002$ & 0.9894 \\
Spleen & $0.0028 \pm 0.0001$ & $0.0027 \pm 0.0001$ & $0.0020 \pm 0.0002^{* * * \#}$ & 0.0054 \\
$\quad$ Thymus & $0.0023 \pm 0.0002$ & $0.0024 \pm 0.0002$ & $0.0013 \pm 0.0001^{* *, \#}$ & 0.0014 \\
Testis & $0.0112 \pm 0.0003$ & $0.0105 \pm 0.0004$ & $0.0121 \pm 0.0004^{\#}$ & 0.0431 \\
Seminiferous tubule & $0.0019 \pm 0.0001$ & $0.0019 \pm 0.0001$ & $0.0015 \pm 0.0001$ & 0.1505 \\
\hline
\end{tabular}

Each value represents the mean \pm SEM of five animals per group. ${ }^{* * *}$ Significantly different from the control $\left({ }^{*} p<0.05,{ }^{* *} p<0.005\right)$. $\$$,\#Significantly different from the $10 \mathrm{mg} / \mathrm{kg}$ group $\left({ }^{\$} p<0.05,{ }^{\#} p<0.01\right)$.

BPA. The wet liver weights in $50 \mathrm{mg} / \mathrm{kg}$ BPA groups of female and male rats were 73 and $64 \%$ to each control, indicating that male rats were also more vulnerable to the changes of liver weight than female rats. In the spleen, the difference of changes of the wet weight between female and male is much larger. The thymus weights in female and male rats were similarly decreased to about $50 \%$ to the controls, resulting in the most sensitive organs among all organs studied.

\section{Determination of 2-OHE, 4-OHE and estrone by GC/MSD for enzyme assays and urine analysis}

2-OHE, 4-OHE and estrone, the products of the enzymes E2 2- and 4-hydroxylase and 17 $\beta$-hydroxysteroid dehydrogenase, respectively, were produced from the substrate E2. To determine these enzyme products in the reaction medium using $\mathrm{E} 2$ as the substrate and these metabolites in urine of rats treated with BPA, a GC/MSD/selected ion monitoring method was used. The retention times of the typical chromatograms of authentic 2-OHE, 4-OHE, estrone, and methyltestosterone (used as the internal standard) were to be $14.1,15.1,10.6$ and $13.2 \mathrm{~min}$, as shown in Fig. 2, A. No 2-OHE and 4-OHE peaks were detected in the enzyme medium of the blank sample that the substrate was not added in hepatic microsomal fraction from female and male rats, indicating that no interfering peaks were found at the retention time of 2-OHE and 4-OHE (Fig. 2B and D). The regression coefficients for cal- ibration of 2- OHE, 4-OHE and estrone were 0.9951, 0.9916 , and $0.9891(y=0.0293 \times-0.2539, y=0.0207 \times-0.1937$ and $y=0.0704 \times-0.1679$ ), respectively for the ranges from $5-250 \mathrm{ng} / \mathrm{ml}$, showing good linearity and higher precision less than $15 \%$ bias (data not shown). High abundance of 2-OHE, 4-OHE and estrone peaks were observed in the complete enzyme medium with cofactors, substrate and hepatic microsomal fractions from male and female rats (Fig. 2C and E). Since E2 is metabolized to 2-OHE, 4-OHE and estrone, we also determined these metabolites in the presence of ascorbic acid in urine of female rats. While 2-OHE was detected in the urine samples, no 4-OHE and estrone metabolites were found in urine samples of BPA-treated rats (Fig. 2G).

\section{Decreases of benzphetamine N-demethylase activity by BPA}

Optimal conditions of substrate concentration, incubation time and microsome amount for benzphetamine $\mathrm{N}$-demethylase activity were established by a preliminary experiment to be $0.5 \mathrm{mM}$ benzphetamine- $\mathrm{HCl}, 45 \mathrm{~min}$, and $0.2 \mathrm{mg}$ microsomal enzyme, respectively (data not shown). The calibration curve of standard formaldehyde was ranged from 0 to $6.7 \mu \mathrm{g} / \mathrm{ml}$ and showed a good linearity $\left(y=0.5298 \times-0.002 ; r^{2}=0.9997\right)$. The effect of BPA on benzphetamine $\mathrm{N}$-demethylase activity was observed. The activity was $0.204 \pm 0.017 \mathrm{nmole} / \mathrm{min} / \mathrm{mg}$ protein in control group of female rats. The enzyme activity was significantly 

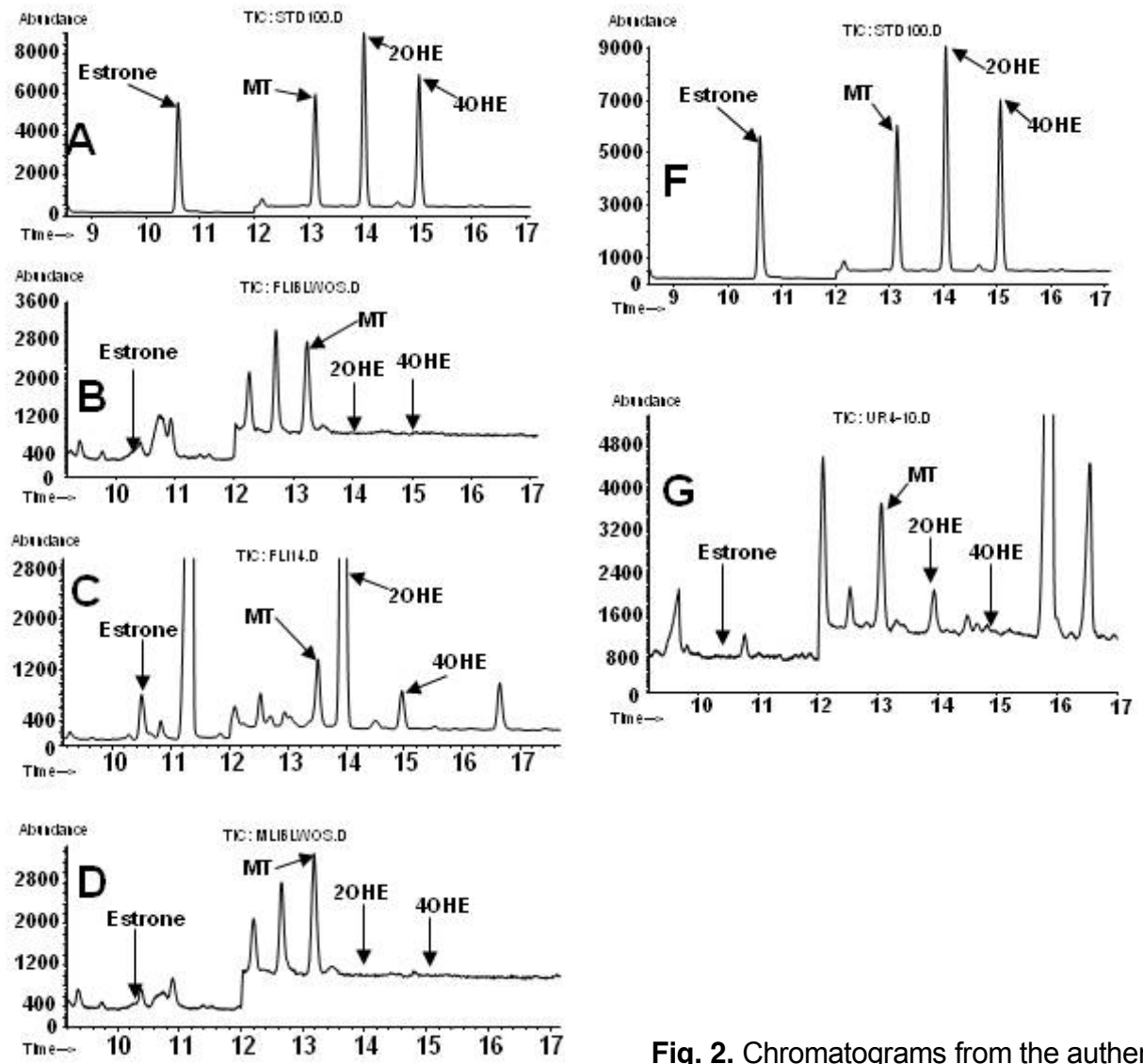

Fig. 2. Chromatograms from the authentic compounds (A), blanks in female (B) and male (D) rats in the absence of hepatic microsomal enzyme, and samples of hepatic microsomal fractions in female $(C)$ and male $(E)$ rats were shown in each panel. Enzyme reaction was made and the enzyme products were determined by GC/MSD as described in the Materials and Methods section. And for the analysis of estrogen metabolites in urine of female rats treated with BPA, chromatograms of estrogen metabolites were presented for authentic compounds $(F)$ and a urine sample (G). MT: methyltestosterone, 2-OHE: 2-hydroxyestradiol, 4OHE: 4-hydroxyestradiol.

decreased after treatment of BPA in 10 and $50 \mathrm{mg} / \mathrm{kg}$ BPA (10 mg/kg, $0.155 \pm 0.010 ; 50 \mathrm{mg} / \mathrm{kg}, 0.145 \pm 0.009 \mathrm{nmole} /$ $\mathrm{min} / \mathrm{mg}$ protein; $\mathrm{F}_{2,12}=6.63, p=0.012$ ) by 24 and $29 \%$, respectively, compared to control. Although benzphetamine $\mathrm{N}$-demethylase is expressed by various different isoforms of CYP, CYP2B1 is a major subfamily for being measured by benzphetamine $\mathrm{N}$-demethylase activity (Armstrong and Hollenberg, 1999). Therefore, BPA inhibits the CYP2B1 subtype in rats treated with 10 and $50 \mathrm{mg} / \mathrm{kg}$ BPA.

\section{Effects of BPA on estradiol 2- and 4-hydroxylase acti- vities}

Effects of BPA treatment on the enzymes: Optimal conditions for estradiol 2-hydoxylase assay were determined (data not shown). The optimal substrate concentration of
$17 \beta$-estradiol was $40 \mu \mathrm{M}$, and $0.1 \mathrm{mg}$ of microsomal protein and 5 min for incubation time were selected for the assay. Enzyme medium and urine samples included ascorbic acid to protect the oxidative metabolism of 2- and 4-OHE. The reaction of the microsomal protein to BPA in vitro resulted in remarkable inhibition of estradiol 2-hydoxylase activity and 50\% inhibition concentration was observed at about $40 \mu \mathrm{M}$ BPA (Fig. 3).

E2 2-hydroxylase activity in female rats was inhibited by $46 \%$ at $10 \mathrm{mg} / \mathrm{kg}$ BPA group and by $56 \%$ at $50 \mathrm{mg} / \mathrm{kg}$ group in hepatic microsomal fraction, compared with the control. The same enzyme activity was inhibited by $68 \%$ at the $10 \mathrm{mg} / \mathrm{kg}$ dose and by $82 \%$ at the $50 \mathrm{mg} / \mathrm{kg}$ dose BPA of male rats. No inhibition of the enzyme activity was found either in kidney or lung of male and female rats given 10 or 


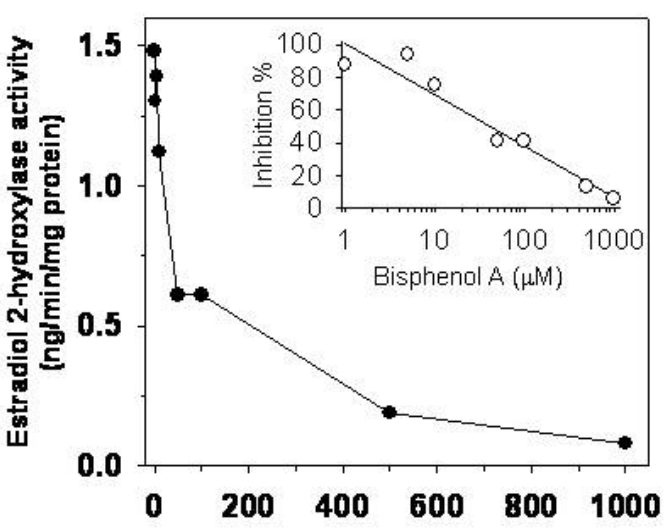

Fig. 3. In vitro inhibition of E2 2-hydoxylase activity by BPA. Various BPA concentrations $(0-1,000 \mu \mathrm{M})$ were added to reaction mixture with the hepatic microsomal fractions of BPA untreated female rats $(0.1 \mathrm{mg}$ protein) and $40 \mu \mathrm{M} 17 \beta$-estradiol as substrate as described in the Materials and Methods section in detail. The reaction of the hepatic microsomal protein to BPA in vitro resulted in the inhibition of E2-2 hydroxylase activity. The log-dose response curves are showed in the inset.

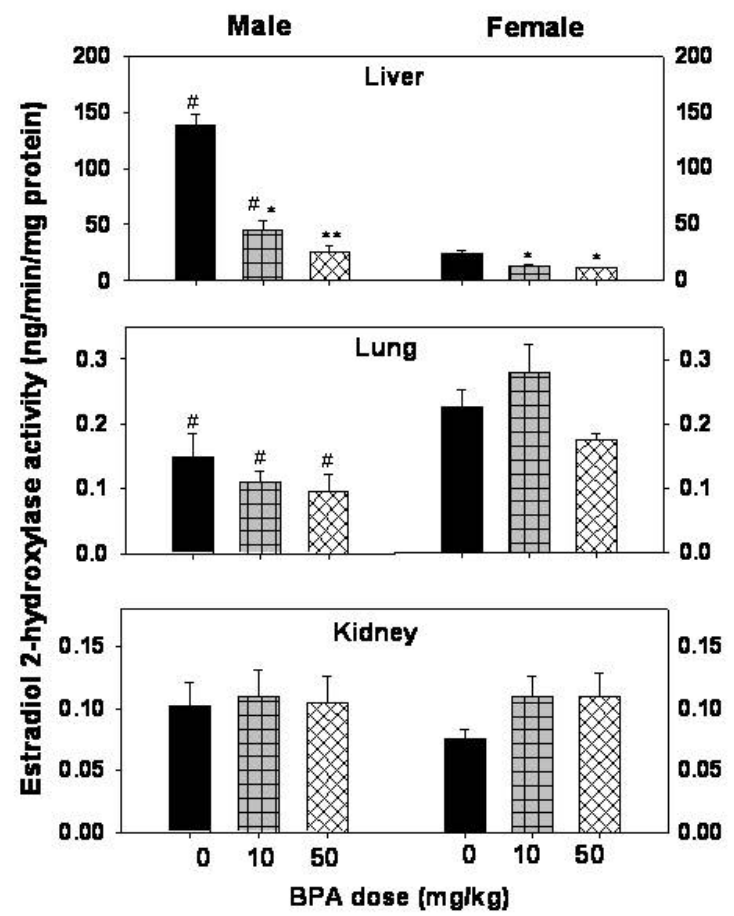

Fig. 4. Estradiol 2-hydroxylase activity in liver, lung, and kidney microsomal fractions of male and female rats. Experimental conditions were carried out as described in the Materials and methods. Each value represents the mean \pm SEM of five animals. The asterisks $\left({ }^{*}\right)$ indicate that the values are significantly different from the control $\left({ }^{*} p<0.05\right)$. "Student's t test between male and female rats in each group was analyzed to compare gender difference $(p<0.005)$.

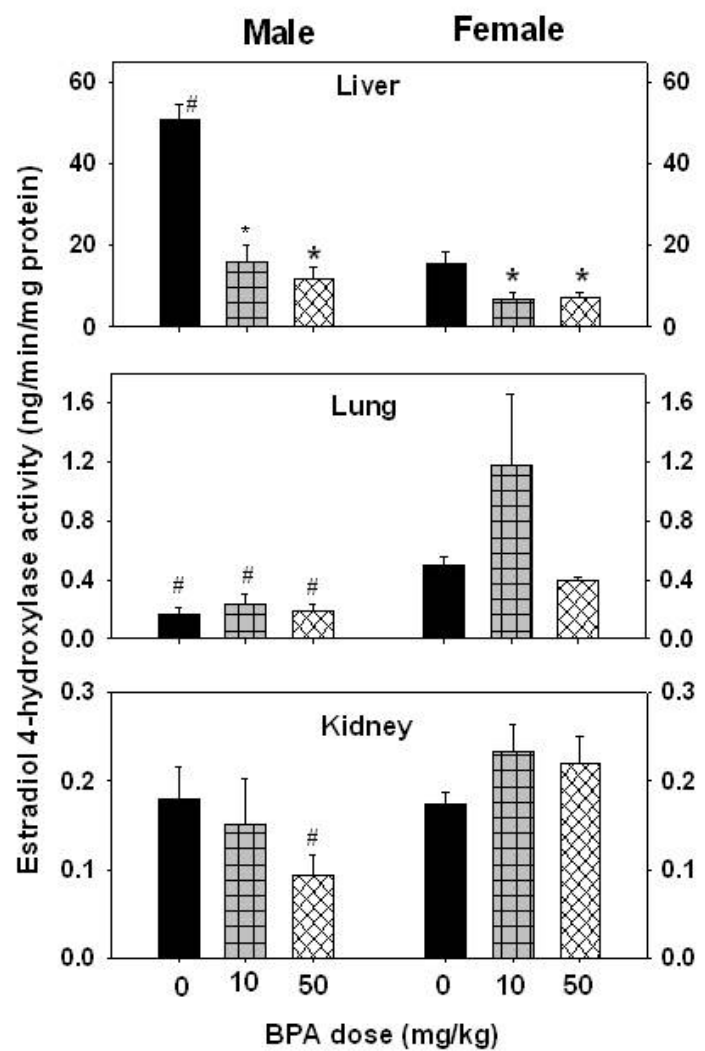

Fig. 5. Estradiol 4-hydroxylase activity in liver, lung, and kidney microsomal fractions of male and female rats. Experimental conditions were carried out as described in the Materials and methods. The asterisks $\left({ }^{*}\right)$ indicate that the values are significantly different from the control $\left({ }^{*} p<0.05\right)$. "Student's $t$ test between male and female rats in each group was analyzed to compare gender difference $(p<0.005)$.

$50 \mathrm{mg} / \mathrm{kg}$ BPA (Fig. 4). The inhibitory percentages of E2 4-hydroxylase were both $57 \%$ at $10 \mathrm{mg} / \mathrm{kg}$ doses and $54 \%$ and $78 \%$ at $50 \mathrm{mg} / \mathrm{kg}$ doses in female and male hepatic $\mathrm{mi}-$ crosomal fractions, respectively. No E2 4-hydroxylase activity was inhibited by BPA in the kidney and lung tissues of male and female rats (Fig. 5).

Effects of gender on the enzymes: By using student's $t$-test, we compared the activity of E2 2-hydroxylase of male rats to that of female rats in each group. The differences of E2 2-hydroxylase activity were found in the hepatic microsomal fraction of the control $(p<0.0001)$ and 10 $\mathrm{mg} / \mathrm{kg}$ dose $(p=0.009)$ groups, and in all groups $(p=0.004$ for control; $p=0.008$ for $10 \mathrm{mg} / \mathrm{kg} ; p=0.018$ for $50 \mathrm{mg} / \mathrm{kg}$ ) of lung tissues, but not in kidney tissues (Fig. 4). The comparison of E2 4-hydroxylase activity between male and female rats results in the difference in the hepatic microsomal fraction of control group $(p<0.0001)$, in lung tissue of control $(p=0.003)$ and $50 \mathrm{mg} / \mathrm{kg}$ dose $(p=0.005)$ groups, and in 
kidney tissue of $50 \mathrm{mg} / \mathrm{kg}$ dose ( $p=0.011$ ) group (Fig. 5).

\section{Effects of BPA on urinary excretion of androsterone, testosterone and 2-OHE}

Endogenous androsterone, testosterone and 2-OHE metabolites in urine of female rats administered to 10 and $50 \mathrm{mg} / \mathrm{kg}$ BPA or vehicle were shown in Fig. 6 . The urinary excretion rates of metabolites androsterone (0-24 hr), testosterone (48-96 hr) and 2-OHE (0-96 hr) in urine were sig-
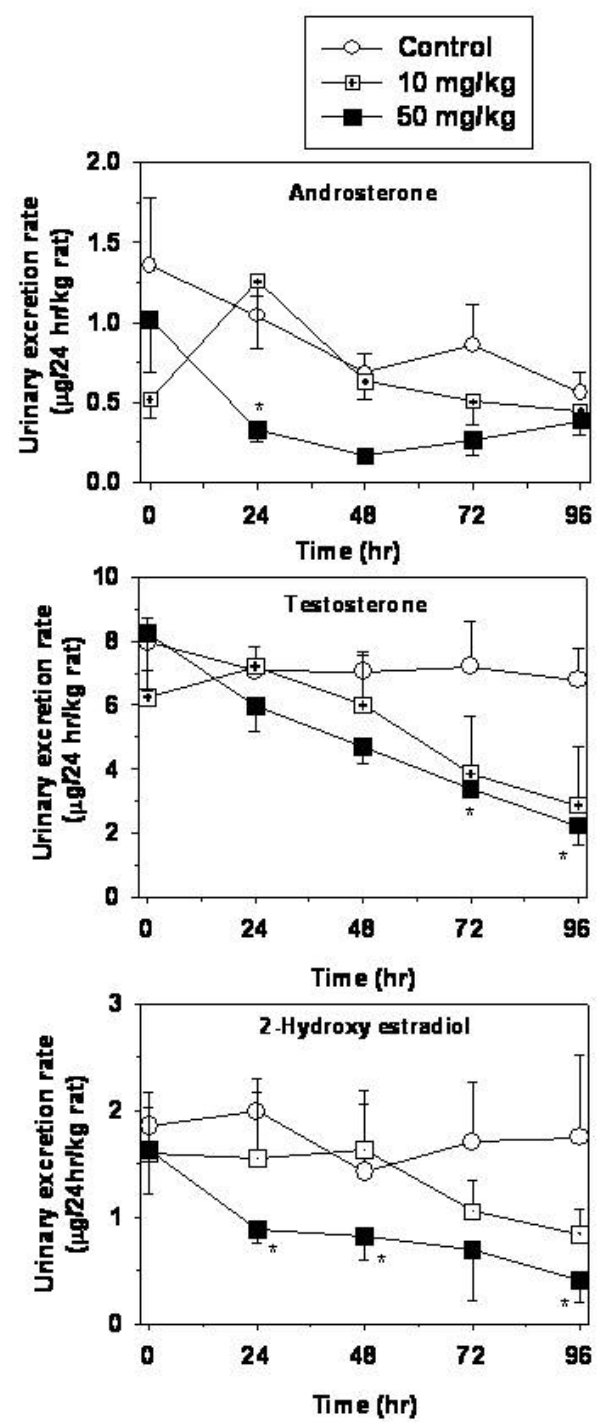

Fig. 6. Urinary excretion rates of $2-\mathrm{OH}$, testosterone and androsterone in the urine of female rats. The urinary excretion rate of androsterone, testosterone and $2 \mathrm{OHE}$ were significantly decreased in 0-24, 48-96 and 0-96 hr periods, respectively. The asterisks $\left(^{*}\right)$ indicate that the values are significantly different from the control $\left({ }^{*} p<0.05\right)$. nificantly decreased at $50 \mathrm{mg} / \mathrm{kg}$ dose group, compared to the control group (Fig. 6). The urinary excretion rates of androsterone, testosterone and 2-OHE were not changed in the $10 \mathrm{mg} / \mathrm{kg}$ dose group. This results support that 50 $\mathrm{mg} / \mathrm{kg}$ dose of BPA treatment inhibits the metabolism of E2 to 2-OHE in rats, and decreased excretion of androsterone and testosterone into urine.

\section{DISCUSSION}

In this work, we measured E2 2- and 4- hydroxylase activity in female and male rats administered to 10 and 50 $\mathrm{mg} / \mathrm{kg}$ BPA with the purpose to investigate whether BPA has effects on the change of the enzyme activity and has effects on gender difference. In our study, the body weights of male and female rats were decreased at 50 $\mathrm{mg} / \mathrm{kg}$ BPA group. Several organ weights were decreased in either male or female rats. As a result, the body and liver weights were more decreased in male than female rats. It has been reported that BPA decreased body and several organ weights of male rats after intraperitoneal administration of BPA at $40 \mathrm{mg} / \mathrm{kg} /$ day for 4 consecutive days (Hanioka et al., 1998). Takahashi and Oishi (2003) reported that subcutaneous treatment of BPA at a dose of $200 \mathrm{mg} / \mathrm{kg} /$ day for 4 weeks significantly decreased the testis and seminal vesicle weights in rats, and subcutaneous treatment of BPA is more toxic than oral administration. And the area under the time-plasma concentration curve of BPA was 245 times higher by subcutaneous than oral administration (Pottenger et al., 2000), suggesting that the dependence of administration routes on BPA toxicity is due to the difference in toxicokinetics. No reports of gender difference in rats exposed to BPA were found. Our data showed that reproductive organs in male rats were more affected than in female rats (Table I and II). Ovary and uterus weights were not changed, but the seminiferous tubule weight was significantly decreased in $50 \mathrm{mg} / \mathrm{kg}$ BPA group, compared to the control. In liver and spleen weights, the inhibition percentage in male rats was higher than that in female rats. BPA is known to be converted to the reactive metabolites. The relative amount of BPA reactive metabolites may be higher in male than female rats, since hepatic E2 2- and 4-hydroxylase activity were about 5- and 3-fold higher in male than in female rats, respectively (Fig. 4 and 5 ).

Endogenous estrogens are hydroxylated at multiple positions by hepatic and non-hepatic microsomal monooxygenase systems. In mammal, hepatic CYP catalyzes $\mathrm{NADPH}$ - dependent oxidation of estrogens to various hydroxylated or keto metabolites (Zhu and Conney, 1998, 
Review). 2-Hydroxylation is the major microsomal metabolic pathway of E2 in the liver of all mammalian species including humans (Dannan et al., 1986; Hammond et al., 1997; Zhu and Conney, 1998; Badawi et al., 2001). In the oxidation of E2 by liver microsomes of female Sprague-Dawley rats 4-hydroxylation is only a minor pathway (Mesia-Vela et al., 2002). In our experiment, E2 2-hydroxylase activity is higher than E2 4-hydroxylase activity in liver (Fig. 4 and 5). Our results showed that E2 2-hydroxylase activity in liver is higher in male than female rats (Fig. 4). These results agree with the report of Suchar et al. (1995) that liver microsomes from male rats were more active those from female rats at catalyzing 2-OHE.

Hepatic hydroxylation of E2 to catechols 2-OHE and 4-OHE in rats is catalyzed by CYP1A1/2, 1B1, 2B1/2, 2C11 and 3A (Yager and Liehr, 1996; Zhu and Conney, 1998; Dawling et al., 2003) and the subfamily CYP1B1 has been identified as a major enzyme catalyzing 4-hydroxylation of E2 (Markides and Liehr, 2005). Furthermore, 2-OHE can be metabolized to 2-methoxyestradiol that has an inhibitory effect on cell proliferation (Seegers et al., 1989; Fotsis et al., 1994; Klauber et al., 1997). In addition, 2-methoxyestradiol disrupts microtubule function and is a potent inhibitor of angiogenesis. Most of cellular effects of 2-OHE are mediated by 2-methoxyestradiol that is devoid of estrogenic activity (Zacharia et al., 2004). Methoxyestradiols exert feedback inhibition on CYP1A1 and 1B1, reducing the oxidative metabolism of E2 to 2-OHE and 4-OHE (Dawling et al., 2003). BPA also interacts with rat hepatic CYP1A2, 2A2, 2B2, 2C11 and 3A2 (Hanioka et al., 2000). The result of our work showed the suppression of E2 2- and 4-hydroxylase activity by BPA in the liver of male and female rats. Suppression of E2 2-hydroxylase activity may result in less production of 2-OHE that is finally lowered the level of 2-methoxyestradiol. The feedback mechanism of methoxyestradiols may increase expression of CYP1A1 and 1B1 (E2 2- and 4-hydrxoylase, respectively), where these enzymes can be used in metabolizing BPA and E2, thus resulting in the inhibition of E2 2- and 4-hydrxoylase activity. It suggests that the suppression of this enzyme disrupts the function of estrogen metabolism.

It is already known that the actions of endocrine disruptors are assumed to be mediated through estrogen receptors, presumably translocating the receptor-ligand complex from the cytoplasm to the nucleus, and inducing the synthesis of estrogen receptor-regulated proteins. BPA exhibited a greater competitive ability for binding to $\beta$ -estrogen receptor than $\alpha$-estrogen receptor (Takemura et al., 2005). The binding of these chemicals to novel estrogen receptors other than $\alpha$ - or $\beta$-estrogen receptor is also plausible (Das et al., 1997; Arcaro et al., 1999). Endocrine disruptors mimic hormones, block and alter hormone binding to receptors, and/or alter the metabolism of natural estrogens (Soto et al., 1995). CYP1B1 is responsible for 4-hydroxylation of E2. In human, the 1B1 is regulated by estrogen via estrogen receptor (Tsuchiya et al., 2004). Since BPA has been reported to bind estrogen receptors ( $\alpha$ and $\beta$ ) and to play either estrogenic or anti-estrogenic roles in vitro (Hiroi et al., 1999; Kurosawa et al., 2002; Takemura et al., 2005), the decreases of E2 4-hydroxylase activity in the target tissue may be due to the competitive binding of BPA to the enzyme with estrogen.

BPA treatment also resulted in significant decreases of the urinary excretion of the metabolite 2-OHE, testosterone and androsterone, depending on time intervals compared to their controls. Androsterone is a metabolite produced from testosterone that can be aromatized to E2 in the ovary or the testis. In our data, excretion rate of testosterone was highly correlated with that of 2-OHE as $r^{2}=0.894$ at $10 \mathrm{mg} / \mathrm{kg} \mathrm{BPA}$ and $\mathrm{r}^{2}=0.922$ at $50 \mathrm{mg} / \mathrm{kg} \mathrm{BPA}$ groups, compared to $r^{2}=0.076$ of the control. Since the urine volume was also significantly decreased in $50 \mathrm{mg} / \mathrm{kg}$ BPA group, compared to the control (data not shown), the decrease of the urinary excretion rate of 2-OHE may be due to depression of the kidney function as well as hepatic inhibition of the enzyme. The levels of BPA in liver and kidney tissues were reported to be 2 to 4 -fold higher than those of the plasma $30 \mathrm{~min}$ after a single intravenous administration of $10 \mathrm{mg} / \mathrm{kg}$ BPA to pregnant rats (Moors et al., 2006). The rapid distribution of BPA to highly bloodperfused organs such as liver and kidney may be sufficient to alter normal functions of the organs.

Taken it together, BPA treatment decreased E2 2- and 4-hydroxylase activity in hepatic microsomal fraction, but not lung and kidney of female and male rats. These data indicate that the effects of BPA on E2 2- and 4-hydroxylase activity are different among liver, kidney, and lung tissues. The differences of E2 2- and 4-hydroxylase activity on genders suggest that the enzymes are specific to gender. These results provide evidence that BPA disrupts the estrogen metabolism differentially by inhibiting E2-2 and 4-hydroxylase activity at relatively high doses of BPA in both male and female rats.

\section{REFERENCES}

Armstrong, A. P. and Hollenberg, P. F. (1999). Mechnismbased inactivation of rat liver cytochrome P-450 2B1 by 2-methoxy-5-nitrobenzyl bromide. Drug. Metab. Dispo. 27, 741-745

Arcaro, K. F., Vakharia, D. D., Yang, Y. and Gierthy, J. F. (1999). 
$2,2^{\prime}, 6,6^{\prime}-$ Tetrachlorobiphenyl is estrogenic in vitro and in vivo. J. Cell Biochem. 72, 94-102.

Arınc, E., Arslan, S. and Adali, O. (2005). Differential effects of diabetes on CYP2E1 and CYP2B4 proteins and associated drug metabolizing enzyme activities in rabbit liver. Arch. Toxicol. 79, 427-433.

Atkinson, A. and Roy, D. (1995a). In vitro conversion of environmental estrogenic chemical bisphenol A to DNA binding metabolite(s). Biochem. Biophys. Res. Commun. 210, 424433.

Atkinson, A. and Roy, D. (1995b). In vivo DNA adduct formation by bisphenol A. Environ. Mol. Mutagen. 26, 60-66.

Badawi, A. F., Cavalieri, E. L. and Rogan, E. G. (2001). Role of human cytochrome P450 1A1, 1B1, and 3A4 in the 2-, 4-, and $16 \alpha$-hydroxylation of $17 \beta$-estradiol. Metabolism $\mathbf{5 0}$, 1001-1003.

Brotons, A., Olea-Serrano, M. F., Villalobos, M., Pedraza, V. and Olea, N. (1995). Xenoestrogens released from lacquer coatings in food cans. Environ. Health Perspect. 103, 608612.

Dannan, G. A., Porubek, D. J., Nelson, S. D., Waxman, D. J. and Guengerich, F. P. (1986). 17ß-Estradiol 2- and 4-hydroxylation catalyzed by rat hepatic cytochrome $\mathrm{P}-450$ : roles of individual forms, inductive effects, developmental patterns, and alterations by gonadectomy and hormone replacement. Endocrinology 118, 1952-1960.

Das, S. K., Taylor, J. A., Korach, K. S., Paria, B. C., Dey, S. K. and Lubahn, D. B. (1997). Estrogenic responses in estrogen receptor- deficient mice reveal a distinct estrogen signaling pathway. Proc. Natl. Acad. Sci. USA 94, 12786-12791.

Dawling, S., Roodi, N. and Parl, F. F. (2003). Methoxyestradiols exert feedback inhibition on cytochrome P450 1A1 and 1B1. Cancer Res. 63, 3127-3132.

Feldman, D. (1997). Editorial: estrogens from plastic-are we being exposed? Endocrinology 138, 1777-1779.

Fotsis, T., Zhang, Y., Pepper, M. S., Adlercreutz, H., Montesano, H. R., Nawroth, P. P. and Schweigerer, L. (1994). The endogenous oestrogen metabolite 2-methoxyoestradio inhibits angiogenesis and suppresses tumour growth. Nature 368, 237-239.

Gao, N., Nester, R. A. and Sarkar, M. A. (2004). 4-Hydroxy estradiol but not 2-hydroxy estradiol induces expression of hypoxia- inducible factor 1 alpha and vascular endothelial growth factor A through phosphatidylinositol 3-kinase/Akt/ FRAP pathway in OVCAR-3 and A2780-CP70 human ovarian carcinoma cells. Toxicol. Appl. Pharmacol. 196, 124135.

Hammond, D. K., Zhu, B. T., Wang, M. Y., Ricci, M. J. and Liehr, J. G. (1997). Cytochrome P450 metabolism of estradiol in hamster liver and kidney. Toxicol. Appl. Pharmacol. 145 54-60.

Hanioka, N., Jinno, H., Nishimura, T. and Masanori, A. (1998). Suppression of male-specific cytochrome P450 isoforms by bisphenol A in rat liver. Arch. Toxicol. 72, 387-394.

Hanioka, N., Jinno, H., Tanaka-Kagawa, T., Nishimura, T. and Ando, M. (2000). Interaction of bisphenol Awith rat hepatic cytochrome P450 enzymes. Chemosphere 41, 973-978.

Hiroi, H., Inoue, S., Watanabe, T., Goto, W., Orimo, A., Momoeda. M., Tsutsumi. O., Taketani, Y. and Muramatsu, M. (1999). Differential immunolocalization of estrogen receptor- $\alpha$ and $-\beta$ in rat ovary and uterus. J. Mol. Endocrinol. 22 , 37-34.

Klauber, N., Parangi, S., Flynn, E., Hamel, E. and D'Amato, R. J. (1997). Inhibition of angiogenesis and breast cancer in mice by the microtubule inhibitors 2-methoxyestradiol and taxol. Cancer Res. 57, 81-86.

Kurosawa, T., Hiroi, H., Tsutsumi, O., Ishikawa, T., Osuga, Y., Fujiwara, T., Inoue, S., Muramatsu, M., Momoeda, M. and Taketani, Y. (2002). The activity of bisphenol A depends on both the estrogen receptor subtype and the cell type. Endocr. J. 49, 465-471.

Lee, A. J., Cai, M. X., Thomas, P. E., Conney, A. H. and Zhu, B. T. (2003). Characterization of the oxidative metabolites of 17b-estradiol and estrone formed by 15 selectively expressed human cytochrome P450 isoforms. Endocrinology 144, 3382-3398.

Lee, S. H., Han, M. W., Jung, B. H., Lee, J., Kwon, O. S., Pyo H. S., Choi, M. H. and Chung, B. C. (2007). Metabolic approach to evaluate the toxicological effects of nonylphenol with rat urine. Anal. Chem. 79, 6102-6110.

Lee, S. K., Jun, I. H., Kang, M. J., Jeon, T. W., Kim, J. H., Seo, Y. M., Shin, S., Choi, J. H., Jeong, H. G., Lee, S. H., and Jeong, T. C. (2008). Characterization of deoxypodophyllotoxin metabolism in rat liver microsomes. Biomol. Ther. 16, 190-196.

Markides, C. S. A. and Liehr, J. G. (2005). Specific binding of 4-hydroxyestradiol to mouse uterine protein: evidence of a physiological role for 4-hydroxyestradiol. J. Endocrinol. 185, 235-242.

Mesia-Vela, S., Sanchez, R. I., Li, J. J., Li, S. A., Conney, A. H. and Kauffman, F. C. (2002). Catechol estrogen formation in liver microsomes from female $\mathrm{ACl}$ and Sprague-Dawley rats: omparison of 2- and 4-hydroxylation revisited. Carcinogenesis 23, 1369-1372.

Moors, P., Diel, P. and Degen, G. H. (2006). Toxicokinetics of bisphenol $\mathrm{A}$ in pregnant $\mathrm{DA} / \mathrm{Han}$ rats after single i.v. application. Arch. Toxicol. 80, 647-655.

Nash, T. (1953). The colorimetric estimation of formaldehyde by means of the Hantzch reaction. Biochem. J. 55, 416-421.

Noda, M., Komatsu. H. and Sano, H. (1999). HPLC analysis of dental resin composites components. J. Biomed. Mater Res. 47, 374-378.

Olea, N., Pulgar, R. and Perez, P. (1996). Estrogencity of resinbased composites and sealants used in dentistry. Environ. Health Perspect. 104, 298-305.

Pottenger, L. H., Domoradzki, J. Y., Markham, D. A., Hansen, S. C., Cagen, S. Z. and Waechter, J. M. Jr. (2000). The relative bioavailability and metabolism of bisphenol $A$ in rats is dependent upon the route of administration. Toxicol. Sci. $\mathbf{5 4}$ 3-18.

Seegers, J. C., Aveling, M. L., Van Aswegen, C. H., Cross, M. Koch, F. and Joubert, W. S. (1989). The cytotoxic effects of estradiol-17 $\beta$, catecholestradiols and methoxyestradiols on dividing MCF-7 and HeLa cells. J. Steroid Biochem. 32, 797-809.

Soto, A. M., Sonneschein, C., Chung, K. L., Fernandez, M. F., Olea, N. and Serrano, F. O. (1995). The E-SCREEN assay as a tool to identify estrogens: an update on estrogenic environmental pollutants. Environ. Health Perspect. 103 113-122. 
Spink, D. C., Lincoln, D. W., Dickerman, H. W. and Gierthy, J. F. (1990). 2,3,7,8-Tetrachlorodibenzo-p-dioxin causes an extensive alteration of $17 \beta$-estradiol metabolism in MCF-7 breast tumor cells. Pro. Nat. Acad. Sci. USA 87, 6917-6921.

Suchar, L. A., Chang, R. L., Rosen, R. T., Lech, J. and Conney, A. H. (1995). High-performance liquid chromatography separation of hydroxylated estradiol metabolites: Formation of estradiol metabolites by liver microsomes from male and female rats. J. Pharmacol. Exp. Ther. 272, 197-206.

Takahashi, O. and Oishi, S. (2003). Testicular toxicity of dietarily or parenterally administered Bisphenol $A$ in rats and mice. Food Chem. Toxicol. 41, 1035-1044.

Takemura, H., Sayama, K., Terao, Y., Zhu, B. T. and Shimoi, K. (2005). In vitro and in vivo estrogenic activity of chlorinated derivatives of bisphenol A. Toxicology 207, 215-221.

Tsuchiya, T., Nakajima, M. and Yoki, T. (2005). Cytochrome
P450-mediated metabolism of estrogens and its regulation in human. Cancer Lett. 227, 115-124.

Wilson, M. A. and Reed, G. A. (2001). Predominant 4-hydroxylation of estradiol by constitutive cytochrome P450s in the female ACl rat liver. Carcinogenesis 22, 257-263.

Yager, J. D. and Liehr, J. G. (1996). Molecular mechanisms of estrogen carcinogenesis. Ann. Rev. Pharmacol. Toxicol. 36, 203-232.

Zacharia, C. L., Piche, C. A., Fielding, R. M., Holland, K. M., Allison, S. D., Dubey, R. K. and Jackson, E. K. (2004). 2Hydroxyestradiol is a prodrug of 2-methoxyestradiol. $\mathrm{J}$. Pharmacol. Exp. Ther. 309, 1093-1097.

Zhu, B. T. and Conney, A. H. (1998). Functional role of estrogen metabolism in target cells: review and perspective. Carcinogesis 19, 1-27. 